\title{
Voice of Subalterns in Nepali Dohori Geets
}

\author{
Dr. Ramesh Prasad Adhikary \\ Assistant Professor (English) TU P. N. Campus, Pokhara, Nepal \\ rameshadhikary29@gmail.com
}

\begin{abstract}
This research paper is concerned with the question of the representation of subaltern classes--poor, Dalits, women and many other marginalized groups in Nepali Dohori' Geets. By using the concept of subaltern studies and voice of the voiceless, it is studied about the voice of marginal groups and their representation in Nepali Dohori Geet. So, Dohori Geet, despite being orally transmitted as the part of entertainment programme also presents the social situation.
\end{abstract}

Key Words: Folk Song, Dohori Geet, Subaltern, Marginalized, Oral Tradition

\section{General Introduction to Nepali Dohori Geets}

Nepali Dohori Geet was started from Nepali folk songs. In the history of folksong, origin for Dohori Geet was from Jhaure. Dohori Geet is always composed in the form of question and answer. The word Dohori itself means two ways, so Dohori Geet indicates a song which is sung with the exchange of ideas and feelings between two parties, often the lover and beloved.

Dohori Geet is a part of folk literature because it has been transmitted from one generation to another. In the past, the folk literature was been taken as nonsense but now it is regarded as equal as to others. Dohori Geet is becoming even more popular among Nepalese ears, thanks to these adoptions by commercialization and the lovers of this genre in foreign countries.

Being a part of folksong, Dohori Geet represents the folk culture. Hence folk culture is the basic subject matter of Dohori Geet. Tulsi Diwasa comments that there is no rigid idea regarding the subject matter of Dohori Geets. Some Dohoris are about the subject matter of love whereas some are about socio-political context. Some songs also deal with the issue of population, health and other topics of social concern.

Most of the Dohori Geets are mainly sung on the subject matter of love and especially when the male participant tries to coax the lady to get married with him. In these songs we can have the male ideology because the male wants to show his superiority over female. He proposes to her because he is superior to female. He likes her because she is more beautiful than full moon itself. The female replies, "I can't get marry you because society does not let me do soll. So, although patriarchal ideology operates through these songs, women are equally powerful because they can vent their opinion in the ardent exchange of words. But in other songs the participant lady might 
be from the privileged family, whereas the boy may be from the underprivileged class, resulting discrepancy between the families for marriage settlement.

\section{II}

Nowadays, Dohori Geet has become a popular mode of entertainment and is used for religious as well as educational purposes. The political context is becoming another major part of Dohori Geet.

Likewise popular Dohori singer, Bishnu Khatri comments, love is the basic subject matter of these songs while he does not rejects the possibility of other issues. Dohori Geets, to some extent, has contributed in April movement in Nepali politics as well.

About the subject matter, Bam Bahadur Karki,another prominent singer from Gulmi says, "Love should be the basic subject matter of Dohori Geets but we also emphasize other issues nowadays. For example if a man is exploited by others he can express his feelings by his own song."

We have to understand the types of Dohori songs before analyzing them. Chudamani Bandhu categorizes the folk song on the basis of participation, rhym or tone and function. Dohori Geet belongs to the first category. So, if two groups sing a song in certain issue in question and answer method it becomes a Dohori Geet. Regional songs can be classified interms of tone or rhyme. Nowadays, the Dohori Geets are categorized on the basis of tone, as same Dohori Geet is sung differently in the eastern, western and mid eastern regions. And the ritual song can be included in the third category.

In the same way, Khagendra Prasad Luitel and Mohan Raj Sharma categorize the folksongs into two types: evergreen song and seasonal song, Jhaure Geet, Sangani, Deuda, Roila, Khayeli, Salijo, Chudker, Bhajan, Barhamasa, Sisugeet, Shelo, Dhannachal and Palam, Ghanse, Tunga Hakpare, are grouped under the evergreen song. These types of songs are sung anytime, but here they have given another type which is seasonal song. Seasonal songs are sung in certain time;like Magal, Sagun, Teej Geet, Malsiri, Bhailo, Phagu, Asare, Ratauli, Gaura, can be taken in this category. Teej Geets are sung onlyat the time of Teej as are other Geets are also sung in certain occasions. Chudamani Bandhu comments on the Dohori Geet regarding to its origin: Dohori Geet has been developed as a game and in this very game two participants must be there. To enter into the root of the Dohori Geet we must take two figures Dev Bahadur Dura and Panche Subba. Both figures are the pioneers of Dohori Geet according to hearsay, Panche subba sang the Dohori Geet with the Darauni from Handigaun for twelve years. Likewise Dev Badhur got victory in Dohori game with a woman and makes her his wife. (140)

Nepali popular folk singer Bam Bahadur Karki hereby divides Dohori Geet into three phases; before 2046, around 2046 and after 2046. Dharma Raj Thapa belongs to the first phase as he composed a song Hario danda mathi halo jotne sathi and other songs. Likewise, in the second phase of Dohori, Bam Bahadur Karki himself comes as a representative figure. Besides, Bam Bahadur Karki, Hari Devi Koirala, Krishna Sudha Dhungana, Prajapati Parajuli can be taken as ancestors of Nepali Dohori Geet. Similarly, in the third phase of Nepali Dohori Geets have been produced. And nowadays, these songs are becoming popular. Especially Bishnu Khatri, Badri 
Pangeni, Raju Pariyar, Laxmi Neupane ,Shrijana Birahi Thapa and other so many singers represent this phase. In this third phase the Dohori has been losing its authority. Kancho Suntala is the first Dohori Geet of Nepal which was sung by Bam Bahadur Karki, Kaji Serchan, Harka Bahadur Paija and Nanda Kishor Rana. But this Geet could not come in recorded form. The first recorded Dohori Geet, is Khola pari Nirmaya by Bam Bahadur Karki. Before Khola Pari Nirmaya there was not formally recorded Dohori Geet. In this Dohori Geet, we can find the subject matter of love. Male singer laments that because of rainy season he could not meet his beloved. Male's tone is strong, authoritative and bold, whereas the female's voice is cool and passive. This first Dohori Geet is released by Music Nepal and the first Nepali CD in the history of Dohori was brought in the screen by_Gorkha Touch' in 2048.

Another Folk singer Bishnu Khatri categorizes the folk Dohori Geet in different way. He disagrees with the time factor as the standard of categorization, he categories Dohori Geets on the basis of subject matter. Following are the types he mentions;
a. Issue of love
b. Issue of culture
c. Issue of incident/ event
d. Issue of socio politico condition.

Most of the songs are sung in the issue of love but there are other Geets sung for the knowledge and for him every songs must include one issue in out of them

\section{Oral Literature}

So far as the folk Dohori is concerned it can be taken as oral literature because orality suggests the practice of venting ideas through mouth occupied with strong rituals. We can say that all our mythological books can be included as in oral literature because these are collected events. In other words, all the fragmented concepts are collected in book. The author gives a shape but he does not create the very book. So in mythological books, all the ideas are brought from the existing society and are transmitted from one generation to another. When the books are produced these fragmented beliefs get a shape. Dohori is also that kind of literature in which the fragmented beliefs are collected and sung by a certain person, later he becomes a singer. Balmiki has written Ramayana, the great mythological book for Hindus which Late Bhanu Bhakta Acharya translated into. In the beginning line of Ramayana the writer says:

One day god Narad had gone in the heaven to help innocent people. God Barmha was there and Narad, the messanger of god, asked with Barhma that how the people of kali will get redemption from the different kinds of sin. As an answer, god says that it is only through the means of Ramayana these people can get the redemption from that kind of sin. (2)

In the same way the New Testament version of the Bible states:

The women said unto the ser pant we may eat of the fruit of the treas of the gardens. but of the fruit of the tree which is the midst of the garden, god hath said, ye shall not eat of it neither shall ye touch it, lest ye die: And the ser pant said onto the women, ye shall 
not surely die: for god deth know that in the day ye eat there of, then your eyes shall be opened, and ye shall be as gods knowing good and evil. (33)

This is also a kind of heresy because when it happened and whether it happened or not is not fixed but it has seen collected and has given a shape of a book or a reason behind the birth of mythical books.

Like mythological books, the folk song has the same quality. For example, Bishnu Khatri has sung a folk song Ki Lash Chhaiho Ki Sash Chhahiyo. In this song he has collected the agony of the Nepalese people who become victim in civil war. The dear and near ones want to see either dead body or the life of arrested people in the time of war. Now the revolutionary groups are able to lead the state but their agonies have not disappeared. This is an accident which happened in the society so here folk singer Bishnu Khatri has also recollected these songs from the society itself. In the same way, Badri Pangeni has sung a song Entitled Janta Ko Sasan. This song has been existing in our society but here Badri Pangeni gives a shape to it. In this song we can see the real pathetic articulation of lower class people in the then society. So this is also collected from the society.

In the same way Jeevan Sharma has composed a song named Shimali Chhayan Ma Basi. This song also shows the reality of the lower class people who are fragmented but when he gives a shape as a song it got a shape. So, Dohori Geets share many characteristics associated to traditional oral literature. It has generated from the lived dense condition of people. It also works as the social comment bringing a huge rural populace within a single ideological framework. Since oral ritual expresses often associate themselves with the cultural and religious factor Dohori is not an exception.

\section{Subaltern Studies and voice of the Voiceless}

The word 'subaltern' denotes marginalized or oppressed people whose actions and deeds are not recorded in colonialist historiography during the colonial and post colonial India. As the subaltern people tried to raise the question against colonizers or elite people, they were termed as second class people. Despite being co-operative to dominant authority, they were insulted. As a result, subaltern studies seem to provide the subaltern people with their own history and their own voices. Subaltern studies try to find out their real existence and their contribution in all aspects.

The people who are marginalized and underprivileged they especially belongs into the subaltern group. Those people who are unheard and their faces have to be represented are the people of subaltern group. Spivak has most consistently focused on what in post colonial studies has come to be called the subaltern literally, the category of these who are lower in position or who in the military terms that are always appropriate to the colonial situation are lower in rank. For Spivak the homeless, the unemployed, the subsistence farmers, the day labors and so one are the subaltern. Spivak focus on the female subaltern a very large she has traditionally been doubly marginalized. "If in the context of colonial production the subaltern has no history and can not speak. The subaltern as female in even more deeply in shadow" (qtd. literary theory 212). 
As Spivak says, the female subalterns are doubly marginalized. Hearing after the some Nepali Dohori Geets we can easily feel the representation of those female. Sunko Jalap is an album which raises the problems of female in society after the separation with her husband. Being a poor her husband should leave her for many years. By seeing this as their loopholes the society treat her as foreigner. Here we can see the doubly marginalized of female in terms of economy as well as the identity.

What clearly is left out of this un-historical historiography is domain of elite politics there existed throughout the colonial period another domain of Indian politics in which the principle actors were not the dominant groups of indigenous society [. . .] but the subaltern classes and groups constituting the mass of laboring population and the intermediate starts in town and country that is the people. (Historiography of colonial India 4)

Guha does not mean that the elites have not played any role in the nationalist uprising. The elite politics has always existed in parallel with the politics of subaltern. When the elites have been projected as national heroes, the laboring mass has been forgotten. The historiography of colonial India fails to acknowledge the role of this autonomous domain, thus, as Guha argues fails to "Speak for the nations" (5). The analysis above made in reference with Guha, Chakarburty and seal clearly indicates that the nationalism of India was partially subsides the role of the subaltern people in the history-making process. This very problematic seen in the nationalist historiography justifies the significance of subaltern studies. In other words, subaltern studies attempts to articulate voice or the consciousness long subdued first by the colonialists and than by the national elites. While locating in the historical political context, subaltern study is seen to have developed in the historical context of post-colonialism. Thus post colonial studies can be taken as "the unpleasant babble subaltern voice" (Gandhi, 3). Then question comes, how can the subaltern studies, as a theoretical modality be applicable in the context other than post-colonial? The present research work does not take subaltern in the post colonial sense. The term subaltern refers hare to "the general attribute of subordination [...] expressed especially in terms of [. . ] caste, office and gender. (Guha, qtd. in Gandhi) Therefore the present research focuses in the _subalternity' created by the oppressive gender, caste and economic and the term 'subaltern' denotes the entire people that is subordinate in terms of gender, economy as well as caste" (Sen, 202)

Before analyzing one's subalternization it is necessary to examine the subaltern consciousness. There has always been a debate regarding the subaltern consciousness. When the critics like Gramsci, Catterjee and Bhadra see the contradictory nature of subaltern consciousness, Javeed Alam sees the reverse. For him the subalterns remain immune from the manipulations of the dominate groups: - The ruling classes may control the themes and content of politics or the sources of history, the subaltern or the people will always manage to make themselves heardll (44).

In this regard, Alam does not analyze the socio-economic restriction that the subalterns suffer. Being economically underprivileged, they depend on the elites for their subsistence which demand high price from them. They cannot think and act freely due to their socio economic backwardedness. In this regard, they expose the contradictory consciousness. The man who is 
suffering from the problem of hand to mouth s/he cannot think of anything else because s/he is being chased by the very problem.

Gramsci points out the two different states of subaltern consciousness. In this context, he argues:

The social group in question may indeed have its own conception of the world, even if only embryonic; a conception which manifests itself in action, but occasionally and in flashes, when, that that is the group is acting as an organic totality. But this same intellectual subordinating adopted a conception another group. (Qtd.in ChaterJee's Caste and Subaltern Consciousness) (170).

Gramsci points out that the subalterns do have both autonomous and borrowed consciousness, in which the latter gets included in them by the ruling classes. In such instance, the subaltern remains submissive and subordinate. Adding to this nature of subaltern consciousness, Chaterjee names as - contradictory fragments held together in a more or less haphazard wholell (Cast and Subaltern Consciousness 170). Further exploring this contradictory consciousness, Chartterjee states:

Common sense is the contradictory unity of two opposed elements; one, the autonomous element which states the common understanding of the members of the subaltern group engaged in the partial activity transforming the world through their own labor [...] And other element which is borrowed from the dominant classes and which expresses the fact of the ideological submission of subaltern group. (Cast and Subaltern Consciousness, 171) Subalterns contain the world changing potentiality. Sometimes they articulate or reveal this autonomous world transforming consciousness, whereas at other time they remain subordinate to the ruling ideology. In this regard, the unity of these contradictory states of consciousness constitutes their common sense.

In this regard Raju Pariyar and Krishna Pariyar sing a song titled Rumal Dhoko Chhu. They state the voice of people from the lower caste. They express their voice by means of song.

Boy -There is no single place which is not touched by so called lower caste.

Girl - Don't try to drink the water because it has already been touched by the lower caste.

Boy -The people from the so called lower caste have themselves carved the picture in the statue of god. So don't try to pay it. Girl-Please! Leaders stop, your false speech. And don't express any sympathy to your innocent people. (Rumal Dhoko Chhu, Own Translation)

In this extract, here, they try to articulate the voice of the people from the so called lower caste who have been exploited for long. This is not only the expression of agony but rather a challenging voice threatens the world. They are not only singing rather they are revolting against the ruling system.

\section{Comment on Some Popular Dohori Geets}

Bhariya Dai is a popular Dohori Geet, which is sung by Bishnu Khatri and Bimakumari Dura. Bhariya Dai represents the voice of people who have been exploited for long. Bhariya here indicates a man who survives by carrying the things in the back for the others. Their life is similar to animal which is clearly stated in the song. Being a part of folk song, Dohori Geet is collected 
but not created. Bhariya Dai is collected by Bishnu Khatri who has earned more popularity in the world of Dohori Geet.

Bhariya Daiko Bisaune Bhari is the title song of this album and this is a song of lower class people. In the beginning, the boy's voice seems to be revolutionary because he questions the pattern of society where most of the lower class people are being dominated and they remain unheard. They want to revenge with the upper class people of the society. The boy further states his view in the song like:

Some are masters, whereas others are having their life as of a donkey. Why everything is not equal for all?. Some people are dying out of indigestion, whereas others are dying out of starvation. (Bhariya Dai, Own Translation)

This given extract clearly shows the pathetic condition of the poor who are dying out of starvation. There is a big gulf between rich and poor. Poor are loser and never get anything in their life. In the Marxian terminology, they are called the haves not group who are always in the shadow of the elites. They always remain behind the curtain because they remain always unheard. As Marx claims the proletariat should be in same place, here through the means of song they are being united. As Spivak says the subaltern cannot speak, here Bishnu Khatri becomes a representative figure of those subalterns who are not heard in the society. On the other hand, in this above extract we clearly can see the position of the people who are getting the problem of indigestion which means that these people are exploiting those who are underprivileged. Hierarchy between privileged and those who are dying in search of food can be a theme of this song.

In the same way another participant girl express her feelings in that song by saying that they have to face the problem of rainy season as well as the season of winter when nature becomes enemy for them. In the rainy season, they have to face the problem of shower, and that perennial rain disturbs their work. But even autumn becomes spring for the elites. Here she states that they have to accomplish the position of the elites but does not want to destroy the function of societal structure and status quo rather wants to reach in the position of elites.

Slightly in the different way, being a Dohori Geet, boy again replies to the question of the girl. He says that the children of the elites always read in the advanced school which gives them better knowledge. So they can learn many more things, they can have the better education as a result. They can have good and prosperous life. But those who are facing the problem of hand to mouth, they cannot even think of education because firstly we must have food more than education. So, education is secondary thing for them. Being parents they always have wishes to give better education and make their children good and intelligent. But they dose not have such capacity to give them better education. So not only in the social aspect but also in education they are not heard and always dominated by the so called rule and regulation.

In the same way, girl participant supports boy by saying that the money lender comes to them and asks money to return but it is impossible to return that money to him because they have empty stomach, which always creates problem to them. In their life they have been trapped by debt and they always should bow their head in front of their landlords. They do their work in their life but they never see the sunny morning. Similarly, girl comments that everything is expensive but their 
wage is never increased rather the modernity tries to grab their employment so that very structure of society always treats them as a thing rather than being.

For the Dohori Geet there must be a certain situation which gives proper meaning to that song. So for a Dohori Geet there should be appropriate situation by staying that situation singer sings a song. In this song too we can see a situation of a porter and the pathetic condition of his family. A porter does his work continuously and he is always busy. But he always has been facing the problem of hand to mouth. Since his childhood to old age he has been doing that, but he never gets enough food to eat. The empty stomach is his real enemy which always creates problem to him. On the other hand, the children have also been facing that problem, they cannot go to school in their childhood, and as a result they definitely will face the problem of poverty. Their life also does not become meaningful, as their ancestors do have. So, the poor should obey their masters and in a society a kind of gulf has been created.

As in the climax of drama, there is the climax of exploitation when this exploitation tries to cross a boundary. The exploited group tries to reunite and begin their protest. This song Bhariya Dai is a protest against that exploitation which has been prevalent society for long. This song is not only a protest but this is also a revolution as well. By analyzing this song is a request for to be united to those who have been exploiting. In that song we see an extract which tries to make unite the people who are poor:\| The domination is being continued, if we think we can do everything, till we can live our life in this way? So come on and unite for equality". (Bhariya Dai, Own Translation)

This extract clearly states that these people are facing many problems, they are exploited ruthlessly. They are treated as animal rather than human beings. They have been bearing that kind of domination since their birthday till now. To get rid of that domination, they have to be united with others. After being united, there will be a state mechanism which will lead themselves. But this is their only utopian world because the elites continue their exploitation over these poor people, and are never ready to let them that power. The ultimate subject matter of this song is the dominations of those people who have not any identity in the society.

When a man falls in a problem, he believes on fate. When they do not have food for eating and do not have any clothes for wearing they are compelled to go to foreign land to earn money. The poor are destined to leave their land to save themselves. In compulsion, everything becomes right. Here his wife is also ready to send him in foreign land to earn money with the hope of economically free life. She sings:

Girl: I have to go in to thorny bushes without sandals.

And there is no cloth for me to cover my body. So please go to foreign land and try to earn some money. (Janchhu Malaya, Own Translation)

This extract shows the real condition of women in our society. Women go to jungle to collect grass and woods. She has to go to many thorny bushes without sandals to wear and enough to put on. When the agony becomes unbearable she says that he should go to third country to make some money. Question may arise why the Nepalese people should go to foreign land instead of staying in their own land? We do not have any employment in our land is a proper answer of this question. 
So state does not manage any proper situation for that unemployment. To find little bit work, they must have source and force. So, it clearly shows that the poor people never have such sources and force and they don't have proper education for their life. As a result, they do not have any chance to get the proper job in their own land. So they have to go to foreign land and be laborers for their whole life.

Everybody has their wish to stay together with their family, but poor people do not have chance to stay together because they have to be separated with each other. Otherwise, they will face the problem of starvation.

This song is not merely a song but it carries the essence of poor's life. This song tries to encourage the subalterns who have been facing much exploitation in their life. The state is becoming deaf at this time. It means that our state never hears the voice of these people who are underprivileged.

This song also represents the women subalterns in terms of gender. Our society never accepts the existence of woman as a human being. Here woman cannot go somewhere else to earn some money. It is a duty of male to go outside and find out so many things. But women should engage only in house holding. When a man leaves the house in the name of different activities, he collects experience and becomes able to learn so many things. As a result, he tries to boast in front of his innocent wife. Women should go to jungle instead of school and college. Although they can not afford education, they also can not go outside from the four pillars of the house. Here the meaning of the song is to show the condition of underprivileged in the society, but the indirect connotative meaning is that if there is problem in family woman also can go outside and collect some experiences. When women can see the world through their own eyes their level of consciousness also increases. As a result, they will get their own existence. So here the singer indirectly expresses their experiences through the song. The main essence of the song is that women also should be as equal as man and they should get equal treatment in the society differently. So women are also capable to do each and everything in their life. So, it is not necessary to be dependent for women. So this song has been sung on the basis of this included subject matter. So this song advocates not only for the economic subalterns, but also for the gendered subaltern.

As Dohari Geet touches each and every aspect of a society, so Dohari is becoming popular day by day. Janatako Shasan is a Dohari Geet which tries to encourage Nepalese people to go towards the republican state instead of monarchy. In monarchy there is exploitation each and everywhere but that song says that in the republic we will be prosperous and it will not be necessary to go outside the country to earn money. In one sense this song has been sung with hope of a utopian world. But singer, Badri Pangeni and Anjana Gurung focus on the freedom and if the rulers do not do positive activities for the people s/he should be overthrown from the post. So, here 'Republic' itself symbolizes the end of monarchy and the beginning of the new state.

Trisuliko Kinarma Baluwa Challnehaure saluma Bhari Boki Balbacha Palne haru is the title song of this song. This song is sung for the people who have been doing hard work. But they do not find anything. Singers here address the people to become conscious in political issues. Here, through the means of song, they believe that the people will become conscious politically. Even 
in the age of science and technology people are regarded as subjects. So, the main objective of the song is to rupture the hierarchy between rulers and ruled. Here is an extract from the song. The song has been sung in highly political tone. The songs address the political leaders of the major political parties of our country. Madhav Nepal, Girija Prasad, Koirala, Parchanda Dahal are the three top most leaders in Nepal who are also addressed in the song and advised that you should not take rest of the politics because we have to get victory over the totalitarian government.

This song has been sung only for the freedom of people not for love and culture. For quite a long time the king ruled in our country and they used to play game with the people. None of the king from that history did anything in favor of people. And these totalitarian kings wanted to call themselves an incarnation of god Vishnu. So through this song this position is trying to be revealed as problematic. This song also tries to say people not to obey these tyrannical rules. Although this is a song which carries the political issue and only one objective of the song is to make clear to the people to escape from the dark illusion. This song, moreover, says that what the Nepalese people believe is all illusion and fraud based on superstitions.

Simali chhayama basi bhariya lamo sas phereko tells a story of porter. This is not merely his song but is his expression of his agonies and pains. This song is sung by popular singer Jeevan Sharma who always sings in favor of common people. In his songs, we always see his attempt to inspire people to revolt against tyrannical rule and system. Here, Jeevan Sharma becomes a representative figure for those who survive for eating. The title song of this song is; Simali chhayama basi bhariya lamo sas phereko Umera bhaisako 80 jhan thulo dukhale ghereko

Being a title song it carries the theme of this whole song. As a situation, a porter is carrying things on his back and searching for the shadow of a tree. He is sitting on a platform under a tree and tries to think of his past life. He thinks that he does not have any meaning of life. He cannot live in the present rather he tries to live in the future. But he does not have any hopeful future. This song represents the economically subaltern groups. So, through the voice of Jeevan Sharma the voice of dominated people has been expressed. Here Jeevan Sharma becomes a representative figure of them.

Kishani Dai is another popular song sung by popular Dohori singer Bishnu Khatri. In this song we can hear the agonies of Kishans who are being dominated as slaves in the society. Being a farmer, he should depend on nature but to that dependency nature takes as their fault. Here nature indicates fate as well as god. This song tries to emphasize on the plight of these people who are called farmers in the society.

Because of these farmers, the world living up. But these farmers are neglected as things. If there were not farmers, we even could not think of modern world. Farmers are indifferenced now by the state, authority as well as by the nature. That plight of the farmers is clearly pictured in that song.

Kishani Daiko Halo Ra Juwa Bana Ra Pakha Palauda paluwa, is the title song of this song. This title also reflects the subject matter of song. Kishani Dai who is a security person, who has been doing his work, for long, expresses his feellings like that:

The youth has gone far away by plaguing the field 
How it passed I don't know, if I were military man I would be a pensioner now. About ten pair of oxen and dozens of plough has broken down. (Kishani Dai, Own Translation) In this extract we can hear the pathetic plight of ploughman who is always busy in ploughing the field. In our society plaguing the field is not taken as a reputed job because he is always regarded as a mere ploughman. And plaguing the field is not taken as good job. Moreover it is _not a job' rather it is slavery.

It is slavery in the sense that this job is done for others and others take advantage of the farmers. So who works hard s/he should be far from that benefit. A man is not born as a ploughman rather he is made a ploughman. He has been for many years in the field of landlords but he does not get any benefit by doing this work. In this way, girl participant expresses her feelings like;

Your days have gone by plaguing the field my days have passed by besmearing of landlords.

The leakage roof can not be treated but we do the work in the field but others eating these crops. (Kishani Dai, Own Translation)

This extract represents a true picture of farmers in the society. Although this is a song we can make an image in our mind after hearing these lines of songs. The woman here is wife of the ploughman who says that both of their time has passed away by serving to the others. It means that they are old now by doing the work of other. But they can not do anything for themselves. As a result, their roof of the house is leaking that has been leaking for years. They do not have time to patch their own roof because both of them have to do work in the field of others. On the other hand, they don't have money to maintain that leakage roof. This extract says that those who are underprivileged are exploited. The most striking aspect of this extract is we work in the field but get benefit by others.

This is a bitter reality in each aspect of the society where the workers do the work by doing more and more labor. But they always have to face the problem of hand to mouth but who never see the working field, s/he takes the advantage of this work. Here, singers advocate for the emancipation of workers. In another extract of the song the male singer says:

I have wishes to buy other new cloths for you.

But I am lying to you by saying tomorrow and day after tomorrow. There are so many unfulfilled wishes of our children. So it is better to die rather than live like this. (Kishani Dai, Own Translation)

This extract evokes some sympathy towards him. He says that he has so many wishes regarding his wife. But he has to speak lies even to his own wife, which are not his wishes rather it is his compulsion. This extract says that the poor who have wishes regarding their life should give up their wish because even the essential wishes are not being fulfilled. In the same way, there are dozens of problems of their children. But they can not solve them easily and are confined only in imagination. In the same way he is fed-up by the life itself. So he says that it is better to die than live such life. It is also meaningful because poverty always gives them problem and for the poor that problematic life becomes a burden. In the same way girl comments in this way: 
Corrupt man is able to be millionaire over night but we earn only hundred rupees in a day.

It is difficult to run-up the house holding and has to stay without food.

(Kishani Dai, Own Translation)

This extract shows the corrupted behavior of the people. It is all right that a man, who corrupts, can be a millionaire in single night. For the corrupted one it is not necessary to work but he has enough money but those who are doing their work without any rest never have food for over their stomach.

Slightly in the different way the girl singer expresses, the debt is multiplying day by day as a result they should stay with their debt forever. Not only them but also their coming generation will have faced that kind of problem.

In this way, the singers express the real and pathetic condition of the poor in the society. There is trouble in each and every sector of the society. In this song Bishnu Khatri here becomes a representative figure of subalterns for those who have been exploited but cannot speak. Their history cannot find because they are not heard in the society, so here the singers Bishnu Khatri and Bimakumari Dura are becoming the means of articulation of those who are not heared.

Raju Pariyar and Krishna Pariyar have sung a song titled Rumal Dhoko Chhu. This song reflects the social structure of Nepalese community. This song has been sung on the subject matter of caste. There is a hierarchy between lower caste and the so called higher caste. The people from the lower cast cannot touch to people from the higher caste. This pathetic condition of the society has been addressed in the given song. As a Dohori, this song is also in the form of question and answer but this song has been sung for the social structure and both boy and girl singers comments on the then biased concept society. In the beginning part of the song the boy says: - Is there any pure place? Which is not touched by so called lower caste?

In the song the boy says that in this mortal life everything is touched by the people who are called the lower case so it will only be hypocrisy to say the pure world, if the human beings themselves are being untouched. On the one hand it is Dohori Geet and it gives entertainment to the people but if we see it in the deeper part, it has great philosophy: it says that there is not any concrete god, god is created or constructed out of our beliefs. If, you people are seeking for the god it is only an illusion. So do not try to seek god in stone. According to the singers god is good and good is human being. So, for them god is hidden within human beings themselves.

Sunko Jalapa is another popular song which is collected by Bishnu Khatri and it has been sung by Bishnu Khatri and Bima Kumari Dura. As the situation or the condition is required for each Dohori Geets this song is sung on the situation in which husband goes to the foreign country to earn money to solve the had to mouth problem. On the other sight the wife is suppressed in the village not only by the family but also by the whole society. This song carries the condition of underprivileged and women.

Here Bishnu Khatri tries to show the double suppression of women in the society. In the beginning of the song the boy singer says:

Boy: we have been separating with each other for four years. 
I have sent something to you please take these things.

I want to meet my family at Dashain but that cruel master does not give my salary. (Sunko Jalapa, Own Translation)

Dashain is great festival for Hindus. And especially in Nepali culture at the festival of Dashain all the people come to their home from foreign land and celebrate this festival by living in the same place. But, those who cannot come from foreign land become sad for not having the chance of meeting their relatives. In this extract the boy wants to come and meet of his family. But there is big and Black Mountain in front of him which always disturbs him. It means that there is a large amount of debt which he has to pay to his Mahajan in his village. But in the city, where he has been working for long he cannot get his own wages. So, in the village his wife is suppressed in the name of debt, whereas in the city he himself is exploited by not giving his wages.

If this song is listened carefully we can easily guess the condition of the women in the society. As we Nepalese people are facing the problem of hand to mouth all we Nepalese youths have to go to the foreign land. When a man goes towards foreign country he cannot return before three years. When he goes by leaving his family members at that time the innocent woman is exploited. A master comes in the house and tries to scold her in the sense that she has to pay his debt otherwise she has to stay in his house as a servant.

When husband goes leaving his own wife she has to face many other problems, not only the economic but also the societal problems. In our society a husband is regarded as _whole'. A husband is head or the guardian of the family when he leaves, the society feels that his family is now become the shelter less, and society never takes the woman as a human being .Rather it takes her merely as child so in the view of society a woman cannot be a human. So she is always treated as an infant, which is a concept of our society.

In this way the girl expresses her feelings:

Girl: when will you come?

I am waiting and waiting for you

Please come up to Tihar, it is not necessity

To bring anything to me. (Sunko Jalapa, Own Translation)

In this given extract the woman is pleading to her husband to come at Tihar. She has been waiting for him for long, wants to stay and share all agonies and feelings with her husband. When a husband goes to somewhere else by leaving his family, his family always forward to him. She here requests her husband to come in Tihar, which is the second important festival of Hindus.

\section{IV}

The people, who are dominated and cannot have their own voice in the society, are subalterns. In another word, subalterns are always behind the curtains. Dohori Geet especially is a branch of folk song. Dohori is sung for the different subject matter and there is no area bounded for Dohori Geets. But love is the dominant subject matter of most of the Dohari Geets. Being a folksong, it reflects the folk literature. So by the means of Dohari Geet, we can see the socio-political 
condition of the specific society. So in Dohari, the experiences of marginalized, underprivileged and women are focused. Being a part of folk song, Dohari Geet reflects the folk culture and folksong especially is transmitted from one generation to another.So the Dohari Geet has the quality of oral literature. In our society women are always regarded as things. Women always belong to the lower class and they do not have right to question against the male authority, so women should stay in a shadow of male authority. Presence of male in the family is like the presence of guardian in family. If a male goes somewhere else from his land, his family becomes alone. When there is no guardian, the wife is exploited in the society. She cannot participate in any activity in the society. It is natural that she is mentally weak because of her husband's absence. On the other hand, she is exploited physically in the name of different concepts. The husband goes to foreign land to earn money wants to meet his family. But he cannot come because his master does not give his wage. So, the song especially represents those groups who are exploited economically, socially and the culturally. The present research finds that Dohori Geets are not only sung for entertainment they can even state the problems of people marginalized in terms of economy, gender and caste. The research concludes that Dohori Geet is a medium through which the unheard are heard.

\section{Works Cited}

Acharya, Bhanubhakta. Ramayan. Varanasi: Bombay Pustak Bhawan, 2061.

Alam, Javeed. "Peasantry, Politics and Historiography: Critique of New Trend in Relation to Marxism." Reading Subaltern Studies. Ed. David Luden. Delhi: Permanent Black, 2003. 43-58.

Bandhu, Chudamani. "Lok Katha Ra Lok Kabya". Nepali Lok Sahitya. Kathmandu: Ekata Books, 2058. 195-300.

Bertens, Hans. "Post-Colonial Criticism and Theory". Literary Theory. New York:

2001. 193-217.

Bhadra, Gautam. "The Mentality of the Subalternity: Kantanama or Rajdharma." Subaltern

Studies vol. VI. Ed. Ranjit Guha. New Delhi: Oxford University Press, 1988. 54-92.

Chatterjee, Partha. "Caste and Subaltern Consciousness." Ed. Ranjit Guha, 54-92.

Gandhi, Lela. "After Colonialism." Post-Colonial Theory. New Delhi: Oxford University

Press, 1998. 1-22.

Gramsci, Antinio. "History of the Subaltern Classes: Methodological Criteria." Selection from Prison Note Books. London: Lawarence and Wishart, 1996. 52-55.

Khatri, Bishnu. Bhariya Dai. Kathmandu: Dhaulagiri Cassatte Center.

.........., Kisani Dai. Kathmandu: Dhaulagiri Cassatte Center.

............, Sunko Jalapa. Kathmandu: Dhaulagiri Cassette Center.

Neupane, Laxmi. Janchhu Malaya. Kathmandu: Dhaulagiri Cassatte Center.

Pariyar, Raju. Rumal Dhoko Chhu. Kathmandu: Shila Cassette Center.

Sen, Ashok. "Subaltern Studies: Capital, Class and Community." Subaltern Studies.

New Delhi: Oxford University Press, 1988. 203-206. 
Sharma, Jeevan. Simali Chhaya. Kathmandu: Music Nepal.

Sharma, Mohanraj and Khagendra Luitel. "Nepali Lok Geet Ka Parkarharu Ko Parichaya." Lok Bartabigyan Ra Lok Shitya. Kathmandu: Bidharthi Pustak Bhandar, 2063. 85-140. The Holy Bible. USA: National Publishing Company, 1978.

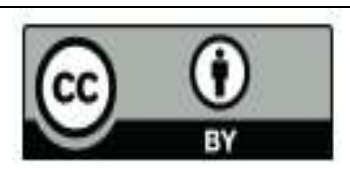

@ 2017 by the author. Licensee University of Chitral, Journal of Linguistics \& Literature, Pakistan. This article is an open access article distributed under the terms and conditions of the Creative Commons Attribution (CC BY) (http://creativecommons.org/licenses/by/4.0/). 